\title{
NABI MUHAMMAD SAW. (Pemimpin Agama dan Kepala Pemerintahan)
}

\author{
Dr. H. M. Dahlan M, M.Ag. \\ Universitas Islam Negeri Alauddin Makassar \\ Email:dahlan@gmail.com
}

\begin{abstract}
This article aimed to know about the process of preaching of the Prophet Muhammad saw. in spreading Islam, and the leadership of the Prophet Muhammad saw. as the leader of the religion and nation. The first principle is the construction of the Masjid, the second is the Ukhuwwah Islamiyyah, the third is the relationship of friendship among other parties that are Muslims.The greatest success of Prophet Muhammad is able to become the leader of the country and religion which has laid on the foundations of politics in the state of life and with it has become the origin of the spread of Islam until it is able to master $2 / 3$ of the world and become the largest religion nowadays.The realization of the Medina Charter is evidence of the nature of the Prophet Muhammad's vision. He not only emphasized Muslims, but he also accommodated the interests of the Jews and united the two peoples under his leadership. The Prophet Muhammad saw. succeeded in creating unity, as well as brotherhood between the Muhajirin and Anshar. Among the Anshar, Prophet Muhammad saw.is admitted to have recaptured the interconnected relations that had always been hostile.
\end{abstract}

Keywords: Leader, Religion, Governor.

\begin{abstract}
Abstrak
Tujuan tulisan ini adalah untuk mengetahui: (1) bagaimana proses dakwah Nabi Muhammad saw. dalam menyebarkan agama Islam, (2) bagaimana kepemimpinan Nabi Muhammad saw. sebagai pemimpin Agama dan pemimpin negara.Dalam rangka memperkokoh masyarakat dan negara baru itu, ia segera meletakkan dasar-dasar kehidupan bermasyarakat. Dasar pertama, pembangunan masjid, Dasar kedua, adalah ukhuwwah islamiyyah, Dasar ketiga, hubungan persahabatan dengan pihak-pihak lain yang beragama Islam.Kesuksesan terbesar Nabi Muhammad adalah mampu menjadi pemimpin negara dan (sekaligus agama) yang telah meletakkan dasar-dasar politik dalam kehidupan bernegara dan dengan hal tersebut telah menjadi cikal bakan tersebarnya agama Islam hingga mampu menguasai $2 / 3$ dunia dan menjadi agama terbesar hingga sekarang. Terwujudnya Piagam Madinah merupakan bukti sifat kenegarawan Nabi Muhammad saw. Beliau tidak hanya mementingkan umat Islam, tapi juga mengakomodasi kepentingan orang Yahudi dan mempersatukan kedua umat seumpun ini di bawah kepemimpinannya. Bagi umat Islam Nabi Muhammad saw. berhasil menciptakan persatuan dan kesatuan, serta persaudaraan antara kaum Muhajirin dan Anshar. Di kalangan kaum Anshar Nabi diakui telah merekat kembali hubungan antarsuku yang sebelumnya selalu bermusuhan.
\end{abstract}

KataKunci: Pemimpin, Agama, Kepala Pemerintahan 
Nabi Muhammad Saw.

\section{A. Pendahuluan}

Kondisi bangsa Arab sebelum kedatangan islam, terutama di sekitar Mekkah masih diwarnai dengan penyembahan berhala sebagai Tuhan. Selain menyembah berhala, di kalangan bangsa Arab ada pula yang menyembah agama Masehi (Nasrani), agama ini dipeluk oleh penduduk Yaman, Najran, dan Syam. Di samping itu juga agama Yahudi yang dipeluk oleh penduduk Yahudi imigran di Yaman dan Madinah, serta agama Majusi (Mazdaisme), yaitu agama orangorang Persia.

Bangsa Arab menjelang kelahiran Nabi Muhammad saw. yang membawa islam di tengah-tengah bangsa Arab. Masa itu biasa disebut dengan massa jahiliah, masa kegelapan dan kebodohan dalam hal agama, bukan dalam hal lain seperti ekonomi dan sastra karena dalam dua hal yang terakhir ini bangsa Arab mengalami perkembangan yang sangat pesat. Mekkah bukan hanya merupakan pusat perdagangan lokal, tetapi juga sebagai jalur perdagangan dunia yang penting saat itu, yang mengubungkan antara utara, syam, dan selatan, Yaman, antara timur, Persia, dan barat Abesinia dan Mesir. ${ }^{1}$

Sebagai agama yang paripurna, Islam tidak hanya mengatur dimensi hubungan manusia dengan Tuhannya, tetapi juga aspek hubungan antara sesama manusia. Selama 23 tahun karier kenabian Muhammad saw., kedua hal ini berhasil dilaksanakannya dengan baik. Pada masa 13 tahun pertama, Muhammad saw. menyampaikan dakwahnya kepada masyarakat Mekkah dengan penekanan pada aspek akidah. Namun bukan berarti bahwa aspek sosial diabaikan sama sekali pada periode ini justru banyak berbicara tentang kecaman terhadap ketidakadilan, praktik-praktik bisnis yang curang, penindasan oleh kelompok elite ekonomi dan politik terhadap kelompok yang lemah dan berbagai kepentingan sosial lainnya serta ancaman siksaan atas perilaku demikian.

Tidak mengherankan kalau pada periode ini pengikut Nabi Muhammad saw. sebagian besar terdiri dari orang-orang yang tertindas dan mengalami ketidakadilan dalam masyarakat. Mereka merasa dimuliakan, karena Islamtidak mengenal stratifikasi sosial yang bersifatmaterial dan artifisial. Hanya ketakwaannya. Akan tetapi, karena pengikut Nabi Muhammad saw. masih sangat sedikit, pesan-pesan wahyu al-Qur'an belum begitu efektif berjalan di tengahtengah hegemoni politik dan ekonomi kam aristokrat Quraisy Makkah. Pengikut Nabi Muhammad saw. yang masih minoritas belum dapat tampil sebagai komunitas yang membongkar tatanan masyarakat Quraisy Mekkah yang timpang tersebut. Bahkan penindasan dan pemusuhan yang dilancarkan oleh kaum kafir Quraisy tehadap Nabi Muhammad saw.. dan pengikutnya semakin hebat.

${ }^{1}$ Samsul Munir Amin, Sejarah Peadaban Islam (Cet. 3; Jakarta: Amzah, 2013), h. 63 
Klimaksnya adalah hijrahnya Nabi Muammad saw. bersama pengikutnya ke Madinah pada 622 M. ${ }^{2}$

\section{Proses Dakwah Nabi Muhammad saw.}

Secara esensial, kelahiran Nabi Muhammad pada masyarakat arab adalah terjadinya kristalisasi pengalaman baru dalam dimensi ketuhanan yang mempengaruhi segala aspek kehidupan masyarakat, temasuk hukum-hukum yang digunakan pada masa itu. Keberhasilan Nabi Muhammad saw. dalam memenangkan kepercayaan bangsa arab pada waktu yang relatif singkat kemampuannya dalam memodifikasi jalan hidup orang-orang Arab. Sebagian dari nilai dan budaya arab pra-islam, untuk beberapa hal diubah dan diteruskan oleh Nabi Muhammad saw.. ke dalam tatanan moral islam. Secara geneologis, ia merupakan keturunan suku Quraisy, suku yang terkuat dan berpengaruh di arab. ${ }^{3}$

Sebelum Nabi Muhammad lahir, ayahnya Abdullah ibn Abdul Muthalib sudah wafat. Dikabarkan Abdullah wafat ketika sedang melakukan perjalanan ke Madinah. Maka, Nabi Muhammad terlahir dalam keadaan seorang anak yatim. Hal ini dijelaskan dalam ayat al-Qur'an berikut ini: (QS.Adh-Dhuhaa $\{93\}$ : 6-8)

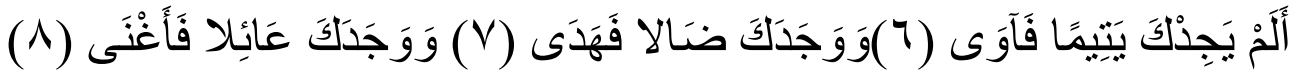
"Bukanlah Dia mendapatimu sebagai seorang yatim, lalu Dia melindungimu, dan Dia mendapatimu sebagai seorang yang bingung, lalu Dia memberi petunjuk, dan Dia mendapatimu sebagai seorang yang kekurangan, lalu Dia memberikan kecukupan".

Allah menegaskan bahwa beliau adalah anak yatim. Tetapi Allah menegaskan pula bahwa Dia akan selalu melindunginya. Bukan cuma itu. Digambarkan Nabi Muhammad juga sering dalam keadaan kebingungan, tetapi Allah selalu memberikan petunjuk-Nya. Bahkan masa kecil beliau selalu dalam kekurangan sebagai anak yatim, tetapi Allah mencukupinya. ${ }^{4}$

Nabi Muhammad saw. dilahirkan pada tahun gajah tahun ketika pasukan gajah Abrahah menyerang Mekkah untuk menghancurkan kabbah, namun pasukan Abrahah mengalami kehancuran. Peristiwa itu terjadi kira-kira pada tahun 570 M (12 Rabiul Awal). Merupakan suatu kebiasaan di antara orang-orang kaya dan kaum bangsaw.an arab bahwa ibu-ibu tidak mengasuh anak-anak mereka, tetapi mereka mengirimkan anak-anak itu ke pedesaan untuk diasuh dan dibesarkan di sana. Begitu pula, Muhammad, setelah di asuh beberapa lama oleh ibunya, dia dipercayakan kepada Halimah dari suku Banu Sa'ad untuk diasuh dan

${ }^{2}$ Muhammad Iqbal, Fiqh Siyasah Kontekstualisasi Doktrin Politik Islam (Cet. 1; Jakarta: Prenadamedia Group, 2014), h. 35-36

h. 59

${ }^{3}$ Dedi Supriadi, Sejarah Peradaban Islam, (Cet. 10; Bandung: CV Pustaka Setia, 2008),

${ }^{4}$ Agus Mustofa, Metamorfosis Sang Nabi (Surabaya: Padma Press, 2008), h. 33-34 
dibesarkan. Dia tetap berada di dalam asuhan Halimah hingga 6 tahun, ketika dia dikembalikan kepada ibunya, Aminah. Pada waktu itu, ibunya bermaksud menziarahi makam suaminya di Madinah, tempat suaminya dimakamkan. Namun, di tengah perjalanan, yaitu di Abwa, Madinah, Aminah mendrita sakit dan menghembuskan nafas yang terakhir di sana. Dengan demikian, pada usia 6 tahun, Muhammad sudah kehilangan kedua orang tuanya.

Setelah Aminah meninggal, Abdul Muthalib mengambil alih tanggung jawab merawat Muhammad. Namun, dua tahun, kemudian Abdul Muthalib meninggal dunia karena renta. Tanggung jawab selanjutnya beralih kepada pamannya, Abu Thalib. Seperti juga Abdul Muthalib, sang paman sangat disegani dan dihormati orang Quraisy dan penduduk Mekkah secara keseluruhan, tetapi dia miskin. Dalam usia muda, Muhammad hidup sebagai pengembala kambing keluarganya dan kambing penduduk Mekkah. Melalui kegiatan pengembalaan ini, dia menemukan tempat untuk berpikir dan merenung. Dalam suasana demikian, dia ingin melihat sesuatu di balik semuanya, pemikiran dan perenungan ini membuatnya jauh dari segala pemikiran nafsu duniawi, sehingga ia terhindar dari berbagai macam noda yang dapat merusak namnya. Oleh karena itu, sejak muda, ia sudah dijuluki al-amin, orang yang terpercaya.

Secara historis, perjalanan Nabi Muhammad saw. sebagai pembawa misi risalah langit, terbagi dalam tiga periode, yaitu pertama, periode pra-kerasulan; kedua, periode kerasulan; ketiga, pasca kerasulan. ${ }^{5}$

Pada usia dewasa, Nabi saw. mulai berusah sendiri dalam penghidupannya, karen aia terkenal seorang yang jujur, maka seorang janda kaya bernama Siti Khadijah mempercayainya untuk membawa barang dagangannya ke Syam. Dalam perjalanannya ke Syam itu, ia ditemani oleh seorang bujang yang bernama Maisarah, setelah selesai menjual belikan barang dagangan di Syam itu dengan memperoleh laba yang banyak, mereka pun kembali ke Mekkah. Setiba di Mekkah, perihal tentang kejujuran Nabi saw. sampai diketahui oleh Khadijah. Bahkan beberapa saat setelah itu, Kahdijah sendirilah yang melamar Nabi saw. untuk dijadikan sebagai pendamping hidup. ${ }^{6}$

Merupakan suatu keharusan mempersiapkan Muhammad saw. secara khusus, utamanya kebiasan-kebiasaan terpuji yang diciptakan oleh Allah untuknya, dalam rangka menyempurnakan kemampuannya dengan sungguh-

${ }^{5}$ Dedi Supriadi, Sejarah Peradaban Islam, h. 60-63

${ }^{6}$ M. Dahlan M, Sejarah Peradaban Islam (SPI): Islam dari Masa Nabi Muhammad saw dan Perkembangan ke Penjuru Dunia di Era Modern (Cet I; Makassar: Alauddin University Press, 2013), h. 18 
sungguh sebelum beliau diserahi kepemimpinan. Persiapan ini meliputi perkaraperkara berikut ini: ${ }^{7}$

1. Muhammad menggembala kambing

Ketika Rasulullah saw. menginjak dewasa, beliau bekerja sebagai penggembala kambing. Beliau keluar dengan kambing-kambingnya ke tempat pengembalaan. Dengan demikian, beliau hidup di tengah-tengah alam yang indah nan tenang yang mampu mendorong terciptanya inspirasi. Pandangannya selalu terarah pada indahnya ciptaan Allah yang sangat berpengaruh dalam pikiran manusia. Merenung dan berpikir (merupakan aktivitas rutinnya). Sehingga hasil dari merenung dan berpikir adalah terciptanya jiwa yang jernih, transparansi ruh dan corak iman yang benar dan kokoh. Sepanjang hari beliau hidup bersama kambingkambing gembalaanya, mengembalikan di antara kambing yang tersesat ke dalam kelompokknya, mengajarnya dengan lemah lembut yang mendorong ketaatan, menjaganya dari serigala buas dan zalim,bersama kambing-kambingnya beliau bejalan menjauhi tempat-tempat tandus, selanjutnya mendatangi tempat-tempat yang baik dan subur (dengan demikian, apa yang beliau lakukan) sama persis sebagaimana yang dilakukan oleh seorang pemimpin yang baik terhadap rakyatnya

2. Banyak melakukan perjalanan

Dengan pamanya, Abu Thalib, Muhammad saw. telah melakukan perjalanan ke negeri Syam dengan membawa barang dagangan Khadijah. Beliau tinggal di negeri Syam tidak hanya sebentar, sehingga di negeri Syam beliau dapat menyaksikan keadaan-keadaan rakyat dan negerinya. Di samping beliau dapat melihat langsung tipe-tipe manusia yang berbeda dengan tipe-tipe manusia yang beliau lihat di Hijaz

3. Mengalami mimpi yang nyata (ar-ru'yah ash-shadiqah)

Ketika masa diserahinya kepemimpinan kepada Muhammad saw., Yakni masa diutusnya sudah dekat, Muhammad saw. mulai mengalami mimpi nyata. Beliau tidak mengalami mimpi, kecuali datang kepadanya seperti cahaya yang memecahkan gelapnya malam (falaq ash-shubhi)

4. Pepohonan dan bebatuan memberi salam kepada beliau

Ibnu Ishaq menuturkan kepada kita, bahwa ketika masa diutusnya Rasulullah saw. sebagai Nabi sudah dekat, maka setiap kali beliau keluar ke tempat-tempat terbuka, jalan-jalan setapak, atau bukit-bukit di Mekkah, maka beliau tidak melewati bebatuan dan pepohonan, kecuali bebatuan dan pepohonan itu mengucapkan, “Assalamu'alaikum, wahai Rasulullah." Mendengar itu beliau

${ }^{7}$ Muh. Rawwas Qol'ahji, Sirah Nabawih: Sisi Politis Peruangan Rasulullah saw (Cet. III; Bogor: Al-Azhar Press, 2007), h. 41 
melihat sekitar, ke kanan, ke kiri, dan belakang, namun beliau tidak melihat seorangpun

5. Senang mengasingkan diri

Mengasingkan diri sambil merenungi nikmat dan karunia Allah awt merupakan ibadah di antara orang-orang Arab yang masih teguh dengan agama Ibrahim (alHanifiyin). Ketika masa penyerahan kepemimpinan kepada Rasulullah saw. sudah dekat, Rasulullah saw. senang mengasingkan diri. Untuk itu, Rasulullah saw. keluar menuju gua Hira, tempat yang berada di dataran tinggi dan jauh dari keramaian

Menurut Michael H.Hart:

"A striking example of this is may ranking Muhammad higher than Jesus, in large part because of my belief that Muhammad had a much greater personal influence on the formulation of the Moslem religion than Jesus had on the formulatin of the Christian religion.

My choice of Muhammad to lead the list of the world's most in fluential persons may surprise some readers and may be questionedby others, but he was the only man in history who was supremely successful on both the religious and secular levels.

Furthemore, Muhammad (unlike Jesus) was a secular as well as a religious leader. In fact, as the driving force behind the Arab conquests, he may well rank as the most influential political leader of the time. ${ }^{8}$

Dengan demikian, Nabi Muhammad saw. telah membangun dalam waktu bersamaan: agama (a religion) dan negara (a state). Dan batas-batas teritorial negara yang ia bangun itu terus terjaga sepanjang hayatnya". Demikian halnya, Schacht berkata: "islam lebih dari sekedar agama: ia juga mencerminkan teoriteori perundang-undangan dan politik. Dalam ungkapan yang lebih sederhana, ia merupakan sistem peradaban yang lengkap, yang mencakup agama dan negara secara bersamaan.

Terkait dengan hal tersebut, R. Strothmann menyatakan bahwa "Islam adalah suatu fenomena agama dan politik. Karena pembangunnya adalah seorang Nabi, yang juga seorang politikus yang bijaksana, atau "negarawan". Islam bukanlah sekedar kepercayaan agama individual, namun ia meniscayakan berdirinya suatu bangun masyarakat yang independen. Ia mempunyai metode tersendiri dalam sistem kepemerintahan, perundang-undangan dan istitusi”.

Seluruh pendapat-pendapat tadi diperkuat oleh fakta-fakta sejarah : di antara fakta sejarah yang tidak dapat diingkari oleh siapapun adalah, setelah timbulnya dakwah islam, kemudian terbentuk bangunan mayarakat baru yang mempunyai identitas independen yang membedakannya dari masyarakat lain. Mengakui satu

${ }^{8}$ Michael H.Hart, The 100: A Ranking of the Most in fluential Persons in Hisstory, (New York, 1918), h. 28-39; Samsul Munir Amin, Sejarah Peadaban Islam, h. 89. 
undang-undang, menjalankan kehidupannya sesuai dengan sistem yang satu, menuju kepada tujuan-tujuan sama. Di antara individu-individu masyarakat yang baru itu, terdapat ikatan ras, bahasa, dan agama yang kuat, serta adanya perasaan solidaritas secara umum. Bangunan masyarakat yang memiliki semua unsur tadi itulah yang dinamakan sebagai bangunan masyarakat 'politik'atau yang dinamakan sebagai 'negara'.

\section{Nabi Muhammad saw. sebagai Pemimpin Agama}

Kepemimpinan Nabi Muhammad saw. sebagai pemimpin agama yakni mencakup seluruh sendi dakwah. Ia terus menyampaikan dakwah dan menyadarkan orang lain. Ia dapat membina, mengatur, dan mengarahkan seluruh pengikutnya tanpa terkecuali. Dalam sejarah dakwa beliau, dapat secara umum dibagi menjadi dua periode sebagai berikut:

\section{Dakwah secara sembunyi-sembunyi}

Menjelang usianya yang keempat puluh, dia sudah terlalu biasa memisahkan diri dari kegalauan masyarakat, berkontemplasi ke gua Hira, beberapa kilometer di Utara Mekkah. Di sana Muhammad mula-mula berjam-jam kemudian berharihari bertafakkur. Pada tanggal 17 Ramadhan tahun 611 M, Malaikat Jibril muncul di hadapannnya, menyampaikan wahyu Allah yang pertama

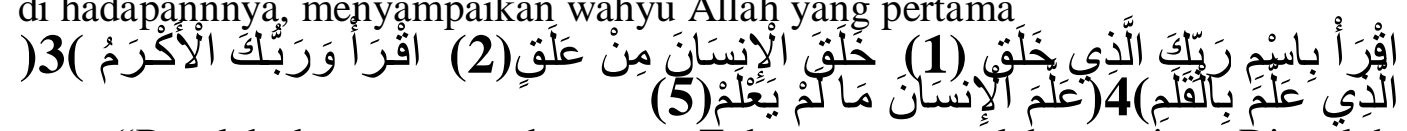

"Bacalah dengan menyebut nama Tuhanmu yang telah mencipta. Dia tëlah menciptakan manusia dari segumpal darah. Bacalah, dan Tuhanmu itu maha Mulia. Dia telah mengajar dengan Qalam. Dia telah mengajar manusia apa yang tidak mereka ketahui.”(Q.S. Al-Alaq: 1-5)

Dengan turunya wahyu pertama itu, berarti Muhammad telah dipilih Tuhan sebagai nabi. Dalam wahyu pertama ini, dia belum diperintahkan untuk menyeruh manusia kepada suatu agama.

Setelah wahyu pertama itu datang, Jibril tidak muncul lagi untuk beberapa lama, sementara Nabi Muhammad menantikannya dan selalu datang ke gua Hira. Dalam keadaan menanti itulah turun wahyu yang membawa perintah kepadanya. Wahyu itu berbunyi sebagai berikut

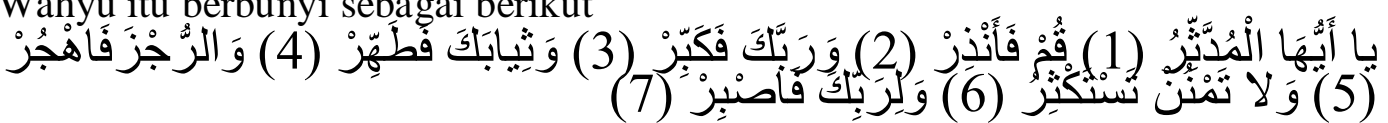

"Hai orang yang berselimut, bangun, dan beri ingatlah. Hendaklah engkau besarkan Tuhanmu dan bersihkanlah pakainmu, tinggalkanlah perbuatan dosa, dan janganlah engkau memberi (dengan maksud) memperoleh (balasan) yang lebihbanyak dan untuk (memenuhi perintah) Tuhanmu bersabarlah. (Q.S. Al-Muddatstssir: 1-7) ${ }^{10}$

\footnotetext{
${ }^{9}$ Firdaus Muhammad, Politik Profetik Reinventing Kepemimpinan Politik Rasulullah (Cet.1; Makassar: Alauddin University Press, 2014), h. 40-41

${ }^{10}$ Badri Yatim, Sejarah Peradaban Islam (Cet.24; Jakarta: PT Rajagrafindo Persada, 2013), h. 19
} 
Pada periode Mekkah, tiga tahun pertama, dakwah Islam dilakukan secara sembunyi-sembunyi. Nabi Muhammad mulai melaksanakan dakwah Islam di lingkungan keluarga, mula-mula istri beliau sendiri, yaitu Khadijah, yang menerima dakwah beliau, kemudian Ali bin Abi Thalib, Abu Bakar sahabat beliau, lalu Zaid, bekas budak beliau. Di samping itu, juga banyak orang yang masuk islam dengan perantaraan Abu Bakar yang terkenal dengan julukan Assabiqunal Awwalun (orang-orang yang lebih dahulu masuk islam), mereka adalah Utsman bin Affan, Zubair bin Awwan, Sa'ad bin Abi Waqqash, Abdur Rahman bin 'Auf, Thalhah bin 'Ubaidillah, Abu 'Ubaidah bin Jarrah, dab AlArqam bin Abil Arqam, yang rumahnya dijadikan markas untukberdakwah (rumah Arqam).

\section{Dakwah secara terang-terangan}

Kemudian setelah turun ayat 94 Surah Al-Hijr, Nabi Muhammad SAW. memulai berdakwah secara terang-terangan.

"Maka sampaikanlah olehmu secara terang-terangan segala apa yang diperintahkan (kepadamu) dan berpalinglah dari orang-orang yang musyrik."(Q.S. Al-Hijr: 94)

Namun, dakwah yang dilakukan beliau tidak mudah karena mendapat tantangan dari kaum kafir Quraisy. Hal tersebut timbul karena beberapa faktor, yaitu sebagai berikut :

1. Mereka tidak dapat membedakan antara kenabian dan kekuasaan. Mereka mengira bahwa tunduk kepada seruan Nabi Muhammad berarti tunduk kepada kepemimpinan Bani Abdul Muthalib

2. Nabi Muhammad menyerukan bersamaan hak antara bangsaw.an dan hamba sahaya

3. Para pemimpin Quraisy tidak mau percaya ataupun mengakui serta tidak menerima ajaran tentang kebangkitan kembali dan pembalasan di akhirat

4. Taklid kepada nenek moyang adalah kebiasaan sangat berat bagi mereka untuk meninggalkan agama nenek moyang dan mengikuti agama Islam

5. Pemahat dan penjual patung memandang Islam sebagai penghalang rezeki

Banyak cara dan upaya yang ditempuh para pemimpin Quraisy untuk mencegah dakwah Nabi Muhammad saw., namun selalu gagal, baik secara diplomatik dan bujuk rayu maupun tindakan-tindakan kekerasan secara fisik. Puncak dari segala cara itu adalah dengan diberlakukannya pemboikotan terhadap Bani Hasyim yang merupakan tempat Nabi Muhammad berlindung. Pemboikotan ini berlangsung selama tiga tahun, dan merupakan tindakan yang paling melemahkan umat islam pada saat itu. Pemboikotan ini baru berhenti setelah kaum Quraisy menyadari bahwa apa yang mereka lakukan sangat keterlaluan. 
Tekanan dari orang-orang kafir semakin keras terhadap gerakan dakwah Nabi Muhammad saw., terlebih setelah meninggalnya dua orang yang selalu melindungi dan menyokong Nabi Muhammad dari orang-orang kafir, yaitu paman beliau, Abu Thalib, dan istri tercinta beliau, Khadijah. Peristiwa itu terjadi pada tahun kesepuluh kenabian. Tahun ini merupakan tahun kesedihan bagi Nabi Muhammad saw. sehingga dinamakan Amul Khuzn.

Karena di Mekkah dakwah Nabi Muhammad saw. mendapat rintangan dan tekanan, pada akhirnya nabi memutuskan untuk berdakwah di luar Mekkah. Namun, di Thaif beliau dicaci dan dilempari batu sampai beliau terluka. Hal ini semua hampir menyebabkan Nabi Muhammad putus asa, sehingga untuk menguatkan hati beliau, Allah SWT mengutus dan mengisra, dan memi'rajkan beliau pada tahun kesepuluh kenabian itu. Berita tentang Isra dan Mi'raj ini menggemparkan masyarakat Mekkah. Bagi orang kafir, peristiwa ini dijadikan bahan propaganda untuk mendustakan Nabi Muhammmad saw. Sedangkan bagi orang yang beriman ini merupakan ujian keimanan.

Setelah peristiwa Isra dan Mi'raj, suatu perkembangan besar bagi kemajuan dakwah Islam terjadi, yaitu dengan datangnya sejumlah penduduk Yastrib (Madinah) untuk berhaji ke Mekkah. Mereka terdiri dari dua suku yang saling bermusuhan, yaitu suku Aus dan Khazraj yang masuk Islam dalam tiga gelombang. Pada gelombang pertama pada tahun kesepuluh kenabian, mereka datang untuk memeluk agama Islam dan menerapkan ajarannya sebagai upaya untuk mendamaikan permusuhan antara kedua suku. Mereka kemudian mendakwahkan Islam di Yatsrib. Gelombang kedua, pada tahun ke-12 kenabian mereka datang kembali menemui nabi dan mengadakan perjanjian yang dikenal dengan perjanjian "Aqabah pertama", yang beisi ikrar kesetiaan. Rombongan ini kemudian kembali ke Yatsrib sebagai juru dakwah disertai oleh Mus'ab bin Umair yang diutus oleh nabi untuk berdakwah bersama mereka. Gelombang ketiga, pada tahun ke-13 kenabian, mereka datang kembali kepada nabi untuk hijrah ke Yatsrib. Mereka akan membai'at nabi sebagai pemimpin. Nabi pun akhirnya menyetujui usul mereka untuk berhijrah. Perjanjian ini disebut perjanjian "Aqabah kedua" karena terjadi pada tempat yang sama.

Akhirnya Nabi Muhammad bersama kurang lebih 150 kaum muslimin hijrah ke Yatsrib. Dan ketika sampai di sana, sebagai penghormatan terhadap nabi, nama Yatsib di ubah menjadi Madinah. ${ }^{11}$

Dalam melakukan aktivitas dakwanya, Nabi saw. menggunakan berbagai media untuk penyebaran pesan-pesan agama Islam. Salah satu media yang digunakan Nabi dalam aktivitasnya berdakwah adalah surat.

\footnotetext{
${ }^{11}$ Samsul Munir Amin, Sejarah Peadaban Islam, h. 65-68
} 
Surat ternyata cukup efektif digunakan sebagai media dakwah. Dan ini dilakukan oleh Nabi saw.. Nabi ternyata memandang perlu untuk berkirim surat kepada para pembesar penguasa wilayah di berbagai daerah untuk menyampaikan ajaran Allah yang diturunkan kepada beliau. ${ }^{12}$

\section{E. Nabi Muhammad saw. sebagai Kepala Negara}

Negara adalah suatu organisasi dalam wilayah yang mempunyai kekuasaan tertinggi yang legal formal dan ditaati oleh rakyatnya. Para intelektual menekankan negara sebagai inti dari politik dan telah memusatkan perhatiannya pada lembaga-lembaga atau institusi kenegaraan dalam bentuk formalnya. Pemahaman seperti ini bersifat terbatas, hanya pada tataran ruang lingkupnya. Pendekatan serupa ini dinamakan pendekatan institusinal (institutional approach).

Pendekatan seperti ini berimplikasi pada pemahaman terhadap negara bahwa politik itu mempelajari kehidupan negara yang meupakan bagian dari kehidupan masyarakat atau mempelajari negara-negara dalam melaksanakan tugas-tugasnya untuk mewujudkan kemaslahatan rakyatsecara umum. ${ }^{13}$

Setelah tiba dan diterima penduduk Yastrib (Madinah), nabi resmi menjadi pemimpin penduduk kota itu. Babak baru dalam sejarah islam pun dimulai. Berbeda dengan periode Makkah, pada periode Madinah, islam, merupakan kekuatan politik. Ajaran islam yang berkenaan dengan kehidupan masyarakat banyak turun di Madinah. Nabi Muhammad mempunyai kedudukan, bukan saja sebagai kepala agama, tetapi juga sebagai kepala negara. Dengan kata lain, dalam diri nabi terkumpul dua kekuasaan, kekuasaan spiritual dan kekuasaan duniawi. Kedudukanya sebagai rasul secara otomatis merupakan kepala negara.

Dalam rangka memperkokoh masyarakat dan negara baru itu, ia segera meletakkan dasar-dasar kehidupan bermasyarakat. Dasar pertama, pembangunan masjid, selain untuk tempat shalat, juga sebagai sarana penting untuk mempersatukan kaum Muslimin dan mempetalikan jiwa mereka, di samping sebagai tempat bermusyawarah merundingkan masalah-masalah yang dihadapi. Masjid pada masa nabi bahkan juga berfungsi sebagai pusat pemerintahan.

Dasar kedua, adalah ukhuwwah islamiyyah, persaudaraan sesama Muslim. Nabi mempersaudarakan antara golongan Muhajirin, penduduk madinah yang sudah masuk Islam dan ikut membantu kaum Muhajirin tersebut. Dengan demikian, diharapkan, setiap Muslim merasa terikat dalam suatu persaudaraan dan kekeluargaan. Apa yang dilakukan Rasulullah ini berarti menciptakan suatu

\footnotetext{
${ }^{12}$ Samsul Munir Amin, Sejarah Peadaban Islam, h 81

${ }^{13}$ Firdaus Muhammad, Politik Profetik Reinventing Kepemimpinan Politik Rasulullah, h. 
bentuk persaudaraan yang baru, yaitu persaudaraan berdasarkan agama, menggantikan persaudaraan berdasarkan darah.

Dasar ketiga, hubungan persahabatan dengan pihak-pihak lain yang beragama Islam. Di Madinah, di samping orang-orang Arab Islam, juga terdapat golongan masyarakat Yahudi dan orang-orang Arab yang masih menganut agama nenek moyang mereka. Agar stabilitas masyarakat dapat diwujudkan, Nabi Muhammad mengadakan ikatan perjanjian dengan mereka. Sebuah piagam yang menjamin kebebasan beragama orang-orang Yahudi sebagai suatu komunitas dikeluarkan. Setiap golongan masyarakat memiliki hak tertentu dalam bidang politik dan keagamaan. Kemedekaan beragama dijamin dan seluruh anggota masyarakat berkewajiban mempertahankan keagamaan negeri itu dari serangan luar. Dalam perjanjian, itu jelas disebutkan bahwa Rasulullah menjadi kepala pemeintahan karena sejauh menyangkut peraturan dan tata tertib umum, otoritas mutlak diberikan kepada beliau. Dalam bidang sosial, juga meletakkan dasar persamaan antar sesama manusia. Perjanjian ini, dalam pandangan ketatanegaraan sekarang, sering disebut dengan Kunstitusi Madinah. ${ }^{14}$

Terwujudnya Piagam Madinah merupakan bukti sifat kenegarawan Nabi Muhammad saw.. Beliau tidak hanya mementingkan umat Islam, tapi juga mengakomodasi kepentingan orang Yahudi dan mempersatukan kedua umat seumpun ini di bawah kepemimpinannya. Bagi umat Islam Nabi Muhammad saw. berhasil menciptakan persatuan dan kesatuan, serta persaudaraan antara kaum Muhajirin dan Anshar. Di kalangan kaum Anshar Nabi diakui telah merekat kembali hubungan antarsuku yang sebelumnya selalu bermusuhan.

Dalam praktiknya, Nabi Muhammad saw. menjalankan pemerintahan yang tidak terpusat di tangan beliau. Untuk mengambil keputusan satu keputusan politik, misalnya, dalam beberapa kasus Nabi melakukan konsultasi dengan pemuka-pemuka masyarakat. Ada empat cara yang ditempuh Nabi dalam mengambil keputusan. Pertama, mengadakan musyawarah dengan sahabat senior; kedua, meminta pertimbangan kalangan profesional; ketiga, melemparkan masalah-masalah tertentu yang biasanya berdampak luas bagi masyarakat ke dalam forum yang lebih luas; dan keempat, mengambil keputusan sendiri. ${ }^{15}$

Kepemimpinan Nabi Muhammad saw.. berjalan di atas nilai-nilai Islam yang berhasil menanamkan keimanan, ketakwaan, kesetiaan dan semangat juang untuk membela kebenaran dan mempertahankan hak selain beroleh bantuan Allah swt.

Selain itu yang perlu diperhatikan ialah, meskipun pada masa Rasulullah orang yang belum mengenal teori pemisahan ataupun pembagian kekuasaan

\footnotetext{
${ }^{14}$ Badri Yatim, Sejarah Peradaban Islam, h. 25-27

${ }^{15}$ Muhammad Iqbal, Fiqh Siyasah Kontekstualisasi Doktrin Politik Islam, h. 43
} 
namun beliau telah mewujudkan dalam pemerintahannya. Pembagian tugas kenegaraan dengan cara mengangkat orang yang memenuhi syarat misalnya wazier (menteri) katib (sekretaris) wali (gubernur) 'amil (pengelola zakat) qadhi (hakim) sudah ada pada masa Rasulullah ${ }^{16}$

Pada titik ini memang layak dimunculkan pertanyaan di mana letak kunci kesuksesan kepemimpinan Nabi Muhammad saw.. Selain memang mendapat petunjuk, bantuan dan perlindungan Allah swt. Ada beberapa kunci yang dapat diteladani oleh umatnya, yaitu:

1. Akhlak Nabi yang terpuji tanpa cela

2. Karakter Nabi yang tahan uji, tangguh, ulet, sederhana, dan bersemangat baja.

3. Sistem dakwah yang menggunakan metode imbauan yang diwarnai dengan hikmah kebijaksanaan.

4. Tujuan perjuangan Nabi yang jelas menuju ke arah menegakkan keadilan dan kebenaran serta menghancurkan yang batil, tanpa pamrih kepada harta, kekuasaan dan kemuliaan duniawi.

5. Prinsip persamaan.

6. Prinsip kebersamaan.

7. Mendahulukan kepentingan dan keselamatan pengikut.

8. memberikan kebebasan berkreasi dan berpendapat serta pendelegasian wewenang

9. Tipe kepemimpinan karismatis dan demokratis.

Keberhasilan Nabi Muhammad saw.. dalam memimpin umat dikarenakan tingkah laku beliau yang selalu berdasarkan Al-Quran dan ditunjang beberapa sifat yang melekat padanya. Adapun sifat utama yang melekat pada diri pribadinya yaitu: ${ }^{17}$

1. Kehormatan kelahirannya.

2. Bentuk dan potongan tubuh yang sempurna.

3. Perkataan yang fasih dan lancar.

4. Kecerdasan akal yang sempurna.

5. Ketabahan dan keberanian.

6. Tidak terpengaruh oleh duniawi.

7. Hormat dan respek terhadap dirinya.

\section{F. Kesimpulan}

Secara historis, perjalanan Nabi Muhammad saw. sebagai pembawa misi risalah Islam terbagi dalam tiga periode, yaitu pertama, periode pra-kerasulan; kedua, periode kerasulan; ketiga, pasca kerasulan. Menjelang usianya yang

161 Muhammad Tahir Azhari, op.cit., h. 119-120. Lihat juga Munawir Sadzali, Islam dan Tata Negara (Cet. V; Jakarta: UI Press 1993), h. 16-17.

${ }^{17}$ https://fastnote.wordpress.com/kepimpinan-nabi-muhammad-s-a-w. 
keempat puluh, dia sudah terlalu biasa memisahkan diri dari kegalauan masyarakat, berkontemplasi ke gua Hira, beberapa kilometer di Utara Mekkah. Di sana Muhammad mula-mula berjam-jam kemudian berhari-hari bertafakkur. Pada tanggal 17 Ramadhan tahun 611 M., Malaikat Jibril muncul di hadapannnya, menyampaikan wahyu Allah yang pertama. Dalam rangka memperkokoh masyarakat dan negara baru itu, ia segera meletakkan dasar-dasar kehidupan bermasyarakat. Dasar pertama, pembangunan masjid, Dasar kedua, adalah ukhuwwah islamiyyah, Dasar ketiga, hubungan persahabatan dengan pihak-pihak lain yang beragama Islam.

Nabi Muhammad saw. dengan kepribadian yang luhur serta memiliki sifat yang menyimpan pesonan yang abadi telah berhasil menyampaikan misi dakwahnya melalui strategi dakwah yang dilakoninya selama kurang lebih 23 tahun.

Kesuksesan terbesar Nabi Muhammad adalah mampu menjadi pemimpin negara dan (sekaligus agama) yang telah meletakkan dasar-dasar politik dalam kehidupan bernegara, dengan hal tersebut telah menjadi cikal bakan tersebarnya agama Islam hingga mampu menguasai $2 / 3$ dunia dan menjadi agama terbesar hingga sekarang.

\section{DAFTAR PUSTAKA}

Abdurrahman, Nana Herdiana. Manajemen Bisnis Syariah dan Kewirausahaan. Cet.1; Bandung: CV Pustaka Setia, 2013.

Amin, Samsul Munir.Sejarah Peadaban Islam.Cet. 3; Jakarta: Amzah, 2013.

H.Hart, Michael, The 100: A Ranking of the Most in fluential Persons in Hisstory. New York, 1918.

https://fastnote.wordpress.com/kepimpinan-nabi-muhammad-s-a-w.

Iqbal, Muhammad.Fiqh Siyasah Kontekstualisasi Doktrin Politik Islam. Cet. 1; Jakarta: Prenadamedia Group, 2014.

Kuntowijoyo, Metodologi Sejarah. Yogyakarta: Tiara Wacana Yogya, 2003.

M. Dahlan M, Sejarah Peradaban Islam (SPI): Islam dari Masa Nabi Muhammad saw. dan Perkembangan ke Penjuru Dunia di Era Modern, Cet I; Makassar: Alauddin University Press, 2013

Muhammad, Firdaus.Politik Profetik Reinventing Kepemimpinan Politik Rasulullah. Cet.1; Makassar: Alauddin University Press, 2014.

Mustofa, Agus. Metamorfosis Sang Nabi. Surabaya: Padma Press, 2008 
Paeni, Mukhlis. Membaca Manusia Bugis-Makassar. CV. Gisna Multi Mandiri Makassar bekerjasama dengan Karunia Kalam Semesta, 2014.

"Membedah Perjanjian Bongaya" (Makalah yang disajikan pada Seminar Membedah Perjanjian Bongaya 1667 oleh Kementerian Koordinator Bidang Maritim dan Sumberdaya, Makassar, 21 Desember 2015.

Pelras, Christian. The Bugis, terj. Abdul Rahman Abu dkk., Manusia Bugis. Jakarta: Nalar bekerjasama dengan Forum Jakarta-Paris 2006.

........, The Bugis; The Peoples of South-East Asia and the Pacific, (Oxford: Blackwell Publishing, tth.

Perpustakaan dan Arsip Daerah Kabupaten Wajo, Lontarak Latoa.

Poesponegoro, Marwati Djoened, Sejarah Nasional Indonesia III, Cet. VIII, Jakarta: Balai Pustaka, 1993.

Pradadimara, Dias \& Muslimin A.R. Effendy, Kontinuitas \& Perubahan dalam sejarah Sulawesi Selatan. Yogyakarta: Ombak, 2004.

Poelinggomang, Edward L, Makassar Abad XIX:Studi tentang Kebijakan Perdagangan Maritim. Cet. I, Jakarta: Kepustakaan Populer Gramedia, 2002.

Makassar: De La Macca, 2012.

Qol'ahji, Muh. Rawwas. Sirah Nabawih: Sisi Politis Peruangan Rasulullah saw., Cet III; Bogor: Al-Azhar Press, 2007

Rasdiyanah, Andi, Latoa: Lontarak Tana Bone, Cet. I, Makassar: UIN Alauddin University Press, 2014.

Rahim, Abdul, Pappaseng Wujud Idea Budaya Sulawesi Selatan, Makasssar: Bidang Sejarah dan Kepurbakalaan Dinas Kebudayaan dan Kepariwisataan Provinsi Sulawesi Selatan, 2012.

Rahman, Nurhayati. Kearifan Lingkungan Hidup Manusia Bugis Berdasarkan Naskah Meong Mpaloe. Makassar: La Galigo Press, 2009.

Rahim, H. A. Rahman. Nilai-Nilai Utama Kebudayaan Bugis. Yogyakarta: Ombak, 2011.

Reid, Anthony, Charting the shape of early modern Southeast Asia, terj. Sori Siregar dkk., Sejarah Modern Awal Asia Tenggara:Sebuah Pemetaan. Cet. I, Jakarta: Pustaka LEP3ES Indonesia, 2004. 
..............., Southeast Asia in the Age of Commerse 1450-1680, terj. Mochtar Pabottingi, Asia Tenggara Dalam Kurun Niaga 1450-1680, Cet I, Jakarta: Yayasan Obor Indonesia, 1992.

.............., Southeast Asia in the Early Modern Era: Trade, Power, and Belief, Ithaca: Cornell University Press: 1993.

Renre, Abdullah. Ibnu Khaldun: Pemikiran, Metode dan Filsafat Sejarah dalam Muqaddimah. Cet 1, Makassar: Alauddin University Press, 2011.

Ricklefs, M.C., A History of Modern Indonesia, terj. Dharmono Hardjowidjono, Sejarah Indonesia Modern, Cet. VI, Yogyakarta: Gadjah Mada University Press, 1998.

Sewang, Ahmad M. Islamisasi Kerajaan Gowa: Abad XVI Sampai Abad XVII. Jakarta: Yayasan Obor, 2005.

Supriadi, Dedi.Sejarah Peradaban Islam. Cet. 10; Bandung: CV Pustaka Setia, 2008.

Yatim, Badri.Sejarah Peradaban Islam. Cet.24; Jakarta: PT Rajagrafindo Persada, 2013. 